\title{
Influence of Professional Status and Conditions of Services on Teacher Productivity in Primary Schools in Zuru Emirate, Kebbi State, Nigeria
}

\author{
Sani Dantani MANAGA, Ph.D \\ Department of Educational Foundations \\ Usmanu Danfodiyo University, Sokoto,Nigeria
}

\begin{abstract}
This study investigated the influence of professional status and condition of service on teacher productivity in primary schools in Zuru Emirate of Kebbi State. A correlational survey design was adopted for the study. Stratified, proportionate and simple random sampling techniques were used to select 346 teachers out of 3,687. Questionnaire and Teacher Productivity Evaluation Format were used as instruments for data collection. The five-point scale instruments were validated by experts and pilot tested and had reliability indexes of 0.83 and 0.85 respectively, using Cronbach Alpha co-efficient. Findings of the study showed that the level of teacher productivity was rated low; professional status and conditions of service were both rated poor. This unfavourable situation has negatively influenced teacher productivity. It was recommended that strategies be put in place to improve teachers' productivity in terms of quality of teaching, record keeping and other activities. The status of teaching should be upgraded and primary school teachers to be provided with better conditions of service to enhance their productivity
\end{abstract}

Keywords: Professional Status, Conditions of Service, Teacher Productivity, Lesson Delivery Record Keeping, Co- Curricular activities

\section{Introduction}

Long before the coming of the Arabs in the $11^{\text {th }}$ century A.D. and the Europeans in the $14^{\text {th }}$ century A.D, respectively. Africans all over the continent and in Nigeria in particular had their traditional system of education by which the young ones were trained to become useful members of their communities. This African indigenous system of education satisfied the economic, political, social and cultural needs of the African people. Parents, siblings, traditional rulers, elders and professionals in various occupations served as teachers (Fafunwa, 2004). When the Arab traders came to Nigeria, the Islamic Scholars who came with them served as teachers while Christian missionaries who later came, doubled as teachers and evangelists under the protection of European colonial masters. Both Islamic teachers and Christian missionary teachers were highly dedicated to their duties and were highly respected in African communities as they brought eastern and western literacy skills as well as Arabic and English language into the Nigerian educational landscape. Most of the schools established by the missionaries were essentially primary schools with very few Teacher Training Colleges spread across Lagos, Abeokuta, Benin, Calabar, Ogbomoso among others (Fafunwa, 2004). The focus was initially on training of Pupil Teachers and Grade III, teachers to handle elementary schools. But from 1960 - 19780's, the emphasis on teacher training was shifted to training of Grade II Teachers to serve in primary schools. At that time, primary school teachers were highly respected and honoured everywhere in Nigeria. Their professional status was regarded with high esteem and headmasters were automatically made to be part of village governing councils in many parts of Nigeria. Primary school teachers were relatively well paid and were highly productive in the discharge of their professional responsibilities. They were consulted in community affairs and produced good products that excelled in secondary and tertiary educational institutions in Nigeria and beyond (Manga, 2015). 
But from 1990's, Grade II Teachers Colleges were abolished as Grade II Teachers Certificate was phased out as an entry qualification into the teaching profession. The Nigeria Certificate in Education (NCE) became the minimum teaching qualification in primary schools as stipulated in the National Policy on Education (Federal Republic of Nigeria, 2013). This was done with a view to uplifting the entry qualification, status of the teaching profession, enhancing condition of service of teachers and ultimately improving their productivity. However, in spite of this major policy shift there have been serious concerns and public outcry by primary school NCE teachers that their professional status is deeply dented and that their conditions of service have deteriorated for the worst. In addition, parents, employers of labour and other stakeholders on education are bitterly complaining that the competence and productivity of primary school teachers have terribly declined to unacceptable levels. It is against this background that this paper sought to find out whether professional status and conditions of service could influence teacher's productivity in primary schools in Zuru Emirate of Kebbi State, Nigeria.

\section{Statement of Problem.}

Teacher productivity is a bedrock for national development. But over the years, the productivity of primary school teachers in Zuru Emirate is seriously doubted. This is because reports by school inspectors, parents, and stakeholders in education tend to indicate that primary school teachers in Zuru Emirate have poor level of productivity as they seem to be deficient in their classroom teaching activities, record keeping and performance of co - curricular activities, which this paper considers as the major indices of measuring teacher productivity (Balogun, 2003). Although teachers generally and honestly admit that their productivity is poor, they vehemently blame it on the bastardization of the professional status of teaching coupled, with the adverse conditions of service under which they are ridiculously expected to operate efficiently and be productive in the practice of their craft.

While the government keeps on insisting that a lot has been done to boost the image of the teaching profession and that so much has also been done to better the lot of teachers, public complaints on the poor quality of primary school products is an indication of poor teacher productivity which have persisted over time. There seems to be no clear evidence on the interrelationship among professional status, conditions of service and teacher productivity in the case of teachers in Zuru Emirate. This study sort to fill this gap. Thus, the main thrust of this study was to investigate whether professional status and conditions of service influences the productivity of primary school teachers in Zuru Emirate of Kebbi State.

\section{Objective of the Study}

The objectives of this study were:

1. to determine the level of productivity of primary school teachers in Zuru Emirate of Kebbi State, Nigeria;

2. to ascertain the professional status of teaching in primary schools in Zuru Emirate of Kebbi State;

3. to assess o conditions of service of teachers in primary schools in Zuru Emirate of Kebbi State; and

4. to investigate the influence of professional status and conditions of service on teacher productivity in primary schools in Zuru Emirate Kebbi State

\section{Research Questions}

1. what is the level of productivity of primary school teachers in Zuru Emirate of Kebbi State Nigeria?

2. What is the of professional status of teaching in primary schools in Zuru Emirate of Kebbi State, Nigeria?

3. What is the condition of service of teachers in primary schools in Zuru Emirate of Kebbi State, Nigeria?

4. Does professional status of teaching and conditions of service influence teachers' productivity in primary schools in Zuru Emirate?

\section{Hypotheses}

The following hypotheses were formulated for the study:

Ho: : Professional status of teaching does not significantly influence productivity among primary school teachers in Zuru Emirate of Kebbi State

$\mathbf{H o}_{2}$ : Conditions of service of teachers does not significantly influence productivity of teachers in primary schools in Zuru Emirate of Kebbi State, Nigeria 


\section{Review of Related Literature}

The status of teaching as a profession in Nigeria has remained controversial and the debate seems to be inconclusive. A profession according to Hornby (2010), is a type of job that requires special training and skills, especially one that needs a high level of education. In some prestigious and highly recognized professions such as Medicine, Law, Engineering and Architecture among others, a high level of education strictly means having a minimum of a first degree in the profession before one is admitted to practice the profession. But in the case of teaching, the Federal Republic of Nigeria (2013:43) in section 5 (92b) of the National Policy on Education states that the minimum qualification for entry into the teaching profession in Nigeria shall be the Nigerian Certificate in Education (NCE). But because the NCE is below the first degree, as such other professionals who are degree holders and above find it extremely difficult to accord NCE teachers the same status as accorded to other professionals.

The level of an individual's professional and academic qualifications tends to determine his or her conditions of service in Nigeria. According to Abdullahi (2013), conditions of service refer to circumstances or situations in which people work, live or do things. These conditions imply that having a good salary and other fringe benefits that are provided to motivate the individual towards higher productivity in the practice of his job. Thus, the theoretical basis of this paper is partly hinged on Abraham Maslow's hierarchy of needs theory in Manga (2015), which states that for an individual to work productively and to attain self actualization, he must have the capacity to satisfy his physiological and psychological needs. By implication, this theory presupposes that for teachers to be productive, their condition of service must be so favourable to such an extent as to enable them to afford the basic necessities of life as well as enjoy some degree recognition, acceptance, status and respect in society. In addition, Hider Fritz's attribution theory in Kpee (2015), contends that a person's behavior can be accounted for by personal and environmental forces. This implies that teachers' level of productivity could be influenced by organizational constraints that can be attributed to environmental forces which determines conditions of service and as well as recognition of professional status of teachers for better or for worse.

\section{Teachers Productivity}

Productivity in the general sense is the production of goods and services that have value or benefit to society. Sofoluwe (2000), defines productivity as the relationship between output of goods and services and the input used in the production process. He gave the equation:

Productivity $=\underline{\text { Total Result Achieved }}=$ Effectiveness

$$
\text { Total Recourses Consumed Efficiency }
$$

In specific terms, Odanuga and Ajila (2000), highlighted that teacher productivity can refer to the effectiveness of teachers in terms of their efficiency in teaching activities, quality of record keeping and affective participation in co-curricular activities. To be termed productive in his teaching job, a teacher is expected to have a sound mastery of his subject area; report to school regularly; attend to his lessons punctually; use instructional materials; and the chalkboard efficiently. To Jumare (2018), productivity in teaching activity includes teacher's ability to use effective teaching methods; good classroom management; clear communication; and effective time utilization. Anuna and Onuoha (2002), noted that a productive teacher is one who regularly fills the time book and signs the movement book as appropriate; ability to develop a comprehensive scheme of work; write daily lesson plans and lesson notes; regularly completes the weekly diary; punctually marks the class register and keeps accurate Continuous Assessment records. Fabgamiye and Durosaro (2000), pointed out that participation in co-curricular activities is a part of teacher productivity which entails the teacher's ability to maintain good relationship with colleagues and pupils; effective execution of additional responsibilities; participation in school sports activities; involvement in school clubs and societies; careful handling and uses of school facilities as well as ability to organize field trips and excursions. This paper adapts the definition earlier given by Odanuga and Ajila (2000), to provide measurable construct of determining he level of productivity of primary school teachers in Zuru Emirate of Kebbi State.

\section{Professional Status and Teachers Productivity}


The fact that the status of teaching as a profession in Nigeria is rated very low is no longer news. What is worrisome is the extent to which the low status of the teaching profession has succeeded in demoralizing, discouraging and paralyzing teachers, particularly at the primary school level from operating to the optimum level of their productivity. Alfa (2015) asserts that the status of teaching profession in Nigeria is poor because teaching has come to be regarded as a job for failures and drop outs. Teaching at the primary school is considered a temporary stepping stone to more lucrative appointments (Madumere, 2004). In addition, teaching is generally seen as a common craft that everyone can join regardless of one's field of study. Thomas (2010), notes that primary school teachers in Nigeria are widely portrayed as being dull, frustrated and incompetent. They are therefore looked upon with disdain and ignored by authorities especially when they voice out their grievances, even when their rights are trampled upon. Teachers are sometimes insulted and humiliated in front of their students, which has resulted in feeling of inferiority complex and threat of job insecurity (Igwe, 2009). This paper draws a lot from these ideas in an attempt to rate the professional status of teaching in primary schools in Zuru Emirate of Kebbi State.

\section{Conditions of Service and Teacher Productivity}

It is generally assumed that good conditions of service engender happiness, commitment to work and higher productivity, while adverse working conditions lead to frustration, rebellion and how productivity. In spite of this, the conditions of service of primary school teachers in Nigeria are generally gloomy and harsh (Oder, 2014). This is because the salary package which is supposed to be the main motivator is grossly inadequate to meet the basic needs of primary school teachers (Nkpotu \& Nwana, 2008). The teachers are not only overloaded with excess workload but also suffer from irregular promotions (Balogun, 2003). They lack decent office and residential accommodation, coupled with lack of transport facilities to ease their daily movement to and from schools (Abdullahi, 2013). Some primary school teachers dress in rags and look like beggars as they cannot afford good clothes and medical services (Ekpo, Amuna \& Okoli, 2012). In addition, primary school teachers lack fringe benefits and job security enjoyed by workers in other professions. Manga (2015), maintain that bad conditions of service makes it extremely difficult for primary school teachers to attain and sustain high level productivity expected of them. This paper sort to verify the extent to which theses gloomy conditions of service affect primary school teachers in Zuru Emirate of Kebbi State.

\section{Methodology}

A correlational survey design was adopted for this study which was carried out in Zuru Emirate of Kebbi State of Nigeria. The total population for the study was 3,687 primary school teachers spread across urban and rural areas in the four local government areas that make up Zuru Emirate. Research Advisors (2006) was used to determine the sample size of 346 teachers from 58 primary schools using stratified, proportionate and simple random sampling techniques. The research instruments used for this study were: Teachers Professional Status and Conditions of Service Questionnaire (TPSCSQ) and the Teacher Productivity Evaluation Format (TPEF) adapted from Odunuga \& AJila (2000). The questionnaire comprised of two sections. Section A was on professional status of teaching while section B was on conditions of service of teachers. Each of these sections had nine items. The Teachers Productivity Evaluation Format was made up of three sections. Section A which measured productivity in terms of quality of teaching activities had eight items. Section B was on teachers' quality of record keeping, while section C was on teachers' participation in extra - curricular activities. The instruments were rated on a five-point scale ranging from $5=($ Very High); 4 = (High); 3 (Moderate); 2 = (Low); and 1 = (Poor). The instruments were a validated by experts in educational management and were pilot tested on teachers outside those that were sampled for the study. Using Cronbach alpha at 0.05 level, the reliability coefficients of 0.835 and 0.852 were obtained for the instruments respectively. The data was collected with the help of trained research assistants who personally visited all the schools to administer the questionnaire, observe teachers in their classroom lesson delivery using the Teacher Productivity Evaluation Format. The data collected was analyzed using simple percentages to answer the three research questions, while Pearson's Product Moment Correlation Coefficient was used to test the hypotheses at 0.05 level of significance. Data was collected with help of trained research assistants. All the 346 copies of the questionnaire were returned and used for the analysis.

\section{Results}

Research Question1: What is the level of productivity of primary school teachers in Zuru Emirate of Kebbi State, Nigeria? 
This research question was answered and presented in table

Table 1: Level of Primary School Teacher's Productivity in Zuru Emirate

\begin{tabular}{|c|c|c|c|c|c|c|}
\hline A & Quality of Teaching Activities & Poor & Low & Moderate & High & V. High \\
\hline & Mastery of subject matter & $15 \%$ & $55 \%$ & $15 \%$ & $10 \%$ & $5 \%$ \\
\hline & Effective use of instructional materials & $20 \%$ & $50 \%$ & $25 \%$ & $3 \%$ & $2 \%$ \\
\hline & Effective use of chalkboard & $10 \%$ & $45 \%$ & $30 \%$ & $8 \%$ & $7 \%$ \\
\hline & Effective application of teaching methods & $13 \%$ & $40 \%$ & $27 \%$ & $10 \%$ & $10 \%$ \\
\hline & Effect use of assessment techniques & $11 \%$ & $57 \%$ & $23 \%$ & $5 \%$ & $4 \%$ \\
\hline & Effective classroom management & $21 \%$ & $53 \%$ & $16 \%$ & $7 \%$ & $3 \%$ \\
\hline & Effective communication & $29 \%$ & $48 \%$ & $11 \%$ & $6 \%$ & $6 \%$ \\
\hline & Effective time management & $30 \%$ & $43 \%$ & $14 \%$ & $9 \%$ & $4 \%$ \\
\hline & Mean = & $19 \%$ & $49 \%$ & $20 \%$ & $7 \%$ & $5 \%$ \\
\hline \multirow[t]{8}{*}{ B } & Quality of Record Keeping & & & & & \\
\hline & Filling of time book and movement book & $15 \%$ & $54 \%$ & $15 \%$ & $5 \%$ & $10 \%$ \\
\hline & Comprehensive of scheme of work & $25 \%$ & $49 \%$ & $20 \%$ & $2 \%$ & $3 \%$ \\
\hline & Adequacy of lesson plan and lesson note & $30 \%$ & $44 \%$ & $10 \%$ & $7 \%$ & $8 \%$ \\
\hline & Filling of school diary book & $27 \%$ & $40 \%$ & $13 \%$ & $10 \%$ & $10 \%$ \\
\hline & Marking of class attendance register & $23 \%$ & $56 \%$ & $11 \%$ & $4 \%$ & $5 \%$ \\
\hline & Keeping continuous assessment records & 215 & $52 \%$ & $14 \%$ & $8 \%$ & $5 \%$ \\
\hline & Mean $=$ & $24 \%$ & $49 \%$ & $14 \%$ & $6 \%$ & $7 \%$ \\
\hline \multirow[t]{9}{*}{$\mathrm{C}$} & Quality of Co - Curricular Activities & & & & & \\
\hline & Relationship with colleagues and pupils & $23 \%$ & $22 \%$ & $51 \%$ & $2 \%$ & $2 \%$ \\
\hline & Execution of additional responsibilities & $30 \%$ & $10 \%$ & $47 \%$ & $9 \%$ & $4 \%$ \\
\hline & Participation in school sports activities & $27 \%$ & $13 \%$ & $46 \%$ & $8 \%$ & $6 \%$ \\
\hline & Involvement in school clubs and societies & $23 \%$ & $21 \%$ & $42 \%$ & $12 \%$ & $2 \%$ \\
\hline & Organization of field trips and excursions & $21 \%$ & $26 \%$ & $40 \%$ & $7 \%$ & $6 \%$ \\
\hline & Careful use of school facilities & $20 \%$ & $11 \%$ & $55 \%$ & $7 \%$ & $7 \%$ \\
\hline & Mean $=$ & $23 \%$ & $17 \%$ & $47 \%$ & $8 \%$ & $5 \%$ \\
\hline & Overall Mean $=$ & $22 \%$ & $38 \%$ & $27 \%$ & $7 \%$ & $6 \%$ \\
\hline
\end{tabular}

Table 1 shows that overall average of productivity of primary school teachers in Zuru Emirate was low as $22 \%$ were scored poor; $38 \%$ were scored low; $27 \%$ were scored moderate. Only $7 \%$ were scored high and $6 \%$ were scored very high on the scale of productivity. This means that majority of teachers $87 \%$ fall within the range of poor, low and moderate productivity while only $13 \%$ fall within the range of high and very high productivity. Section A of table 1 indicates that when it comes to quality of teaching, majority of the teachers $49 \%$ had low productivity; 20\% were moderately productive; $19 \%$ had very low productivity; $7 \%$ had high productivity; and 5\% had very high productivity. Section B of table 1 shows that in terms of record keeping as an index of productivity, majority of teachers $49 \%$ had low productivity; while $6 \%$ had high productivity. Section $\mathrm{C}$ of table 1 indicates that in the area of quality of co - curricular activities as a measure of productivity majority of the teachers $47 \%$ had moderate productivity; $23 \%$ had very low productivity; $17 \%$ had low productivity while only $5 \%$ had very high productivity.

Research Question 2: What is the Professional Status of Teaching in Primary Schools in Zuru Emirate of Kebbi State, Nigeria?

This research question was answered and presented in table 2

Table 2: Profession Status of Teaching in Primary Schools in Zuru Emirate

\begin{tabular}{|l|l|l|l|l|l|l|}
\hline A & Items & Poor & Low & Moderate & High & V. High \\
\hline & Teaching is a noble profession & $60 \%$ & $20 \%$ & $10 \%$ & $7 \%$ & $3 \%$ \\
\hline & Teaching is a lucrative profession & $80 \%$ & $10 \%$ & $4 \%$ & $3 \%$ & $3 \%$ \\
\hline & Teaching has monopoly of special knowledge & $50 \%$ & $30 \%$ & $9 \%$ & $6 \%$ & $5 \%$ \\
\hline & Teaching is a profession only for the trained & $60 \%$ & $25 \%$ & $5 \%$ & $8 \%$ & $2 \%$ \\
\hline
\end{tabular}




\begin{tabular}{|l|l|l|l|l|l|l|}
\hline & Teaching has equal status with other job & $70 \%$ & $15 \%$ & $6 \%$ & $6 \%$ & $3 \%$ \\
\hline & Teaching lacks a strong union & $60 \%$ & $27 \%$ & $5 \%$ & $4 \%$ & $4 \%$ \\
\hline & Teachers feel proud of their profession & $65 \%$ & $18 \%$ & $10 \%$ & $5 \%$ & $2 \%$ \\
\hline Teachers are respected and honored & $75 \%$ & $16 \%$ & $6 \%$ & $2 \%$ & $1 \%$ \\
\hline & Teacher pray for their children to become teachers & $85 \%$ & $10 \%$ & $2 \%$ & $2 \%$ & $1 \%$ \\
\hline & Teachers are regarded as highly intelligent & $65 \%$ & $23 \%$ & $5 \%$ & $4 \%$ & $3 \%$ \\
\hline & Teachers are listened to by authorities & $70 \%$ & $17 \%$ & $6 \%$ & $4 \%$ & $3 \%$ \\
\hline & Teachers hope to remain on the job for life & $60 \%$ & $24 \%$ & $10 \%$ & $3 \%$ & $3 \%$ \\
\hline & Children pray to become teachers when they grow up & $80 \%$ & $11 \%$ & $5 \%$ & $2 \%$ & $2 \%$ \\
\hline & $\mathbf{6 8 \%}$ & $\mathbf{1 9 \%}$ & $\mathbf{6 \%}$ & $\mathbf{4 \%}$ & $\mathbf{3 \%}$ \\
\hline
\end{tabular}

Table 2 indicate that majority of participants $(68 \%)$, rated the professional status of teaching as being very low while (19\%) rated it as low; $(6 \%)$ rated it a moderate; only (4\%) rated it as high; while (3\%) rated it as very high. This means that an overwhelming majority of participant (93\%) rated the status of teaching profession as ranging between poor, low to moderate, while only a negligible and insignificant number (7\%) rated it as being high or very high.

Research Question 3: What is the condition of service of teachers in primary schools in Zuru Emirate of Kebbi State, Nigeria?

This research question was answered and presented in table 3

Table 3: Condition of Service of Primary School Teachers in Zuru Emirate, Kebbi State

\begin{tabular}{|c|l|c|c|c|c|c|}
\hline A & Items & Poor & Low & Moderate & High & V. High \\
\hline & Teachers have adequate salary & $80 \%$ & $10 \%$ & $4 \%$ & $3 \%$ & $3 \%$ \\
\hline & Teachers enjoy regular promotions & $20 \%$ & $30 \%$ & $40 \%$ & $5 \%$ & $5 \%$ \\
\hline & Teachers have suitable accommodation & $50 \%$ & $30 \%$ & $70 \%$ & $7 \%$ & $3 \%$ \\
\hline & Teachers have means of transportation & $15 \%$ & $35 \%$ & $38 \%$ & $7 \%$ & $5 \%$ \\
\hline & Teachers enjoy adequate medical services & $20 \%$ & $30 \%$ & $30 \%$ & $10 \%$ & $10 \%$ \\
\hline & Teachers have job security & $10 \%$ & $20 \%$ & $50 \%$ & $14 \%$ & $6 \%$ \\
\hline & Teachers have moderate workload & $20 \%$ & $60 \%$ & $10 \%$ & $7 \%$ & $3 \%$ \\
\hline & Teachers enjoy special allowances & $10 \%$ & $80 \%$ & $4 \%$ & $3 \%$ & $3 \%$ \\
\hline & Teachers enjoy training programmes & $14 \%$ & $60 \%$ & $14 \%$ & $7 \%$ & $5 \%$ \\
\hline & Mean & $\mathbf{2 7 \%}$ & $\mathbf{3 9 \%}$ & $\mathbf{2 2 \%}$ & $\mathbf{7 \%}$ & $\mathbf{5 \%}$ \\
\hline
\end{tabular}

Table 3 indicate that $(27 \%)$ of participant rated the condition of service of primary school teachers as poor; (39\%) rated it as low; $22 \%$ rated it as moderate; while only (7\%) rated it as high; and (5\%) it as very high. This means that majority of the participants $(88 \%)$ rated the condition of service of teachers to range between poor, low and moderate while only a small minority $(12 \%)$ rated the conditions of services as been high or very high.

Hypothesis 1: Professional status of teaching does not significantly influence productivity of primary school teachers in Zuru Emirate, Kebbi State, Nigeria

This hypothesis was tested and presented in table 4

Table 4: Influence of Professional Status on Teacher's Productivity

\begin{tabular}{|l|l|c|l|l|l|l|l|}
\hline Variable & $\mathrm{N}$ & $\overline{\boldsymbol{X}}$ & $\mathrm{SD}$ & $\mathrm{df}$ & r-cal & P-value & Remark \\
\hline Professional status & 346 & 1.96 & 853 & & & & \\
\hline & & & & 3.45 & .137 & .024 & Significant \\
\hline Teacher Productivity & 346 & 1.33 & 473 & & & & \\
\hline
\end{tabular}


Table 4: showed the number of participants $(\mathrm{N})=346$, and a correlation value of $(r)=.137$ shows that there is a positive relationship between the two variables (professional status and teacher productivity). Testing the hypotheses at alpha level of $(\mathrm{a})=.05$, the $\mathrm{P}$ value of .024 is less than the alpha, hence they hypothesis is rejected. This means that professional status of teaching significantly influences teacher productivity in primary school in Zuru Emirate, Kebbi State.

Hypothesis 2: Condition of service of teachers does not significantly influence teacher productivity school in Zuru Emirate, Kebbi State, Nigeria

This hypothesis was tested and presented in table 5

Table 5: Influence of Conditions of Service on Teacher Productivity in Zuru Emirate

\begin{tabular}{|l|l|l|l|l|l|l|l|}
\hline Variable & $\mathrm{N}$ & $\overline{\boldsymbol{X}}$ & $\mathrm{SD}$ & $\mathrm{df}$ & r- cal & P-value & Remark \\
\hline Conditions of Service & 346 & 1.88 & 872 & & & & \\
\hline & & & & 345 & .135 & .021 & Significant \\
\hline Teacher Productivity & 346 & 1.33 & 473 & & & & \\
\hline
\end{tabular}

Table 5 showed the number of participants $(\mathrm{N})=346$, and a correlation value $(\mathrm{r})=0.135$ indicator that there is a positive relationship between conditions of service and teacher productivity. Testing the hypotheses at alpha level $=0.05$ the $\mathrm{p}$ value is less than the alpha value. Hence the null hypothesis is rejected. This means that condition of service of teachers significantly influenced teacher productivity in primary schools in Zuru Emirate, Kebbi State.

\section{Summary of Findings}

1. The level of teacher productivity in primary schools in Zuru Emirate of Kebbi State, was low.

2. The professional status of teaching in primary schools in Zuru Emirate of Kebbi State, was poor.

3. The condition of service of primary school teachers in Zuru emirate of Kebbi State, was low

4. Professional status of teaching and conditions of service influences teacher productivity in primary schools in Zuru Emirate, Kebbi State

\section{Discussion of Findings}

The first finding of this study shows that the level of teacher productivity in primary schools in Zuru Emirate was rated low by majority of participants as reflected in Table 1. It was found that in terms of quality of teaching activities some teachers lack mastery of their subject matter; do not make effective use of instructional materials; poorly use the chalkboard and had improper teaching methods. Some teachers do not make effective use of assessment techniques; are lacking in effective classroom management; have poor communication skills and poor time management. In terms of quality of record keeping, many teachers do not fill the time book and movement book regularly; have no comprehensive scheme of work; lack adequate lesson plan and lesson note; and do not fill school dairy' book as appropriate. Some teachers do not fill the class attendance registers correctly and are found wanting in the area of continuous assessment of pupils. In terms of quality of co-curricular activities some teachers lack good relationship with colleagues and pupils; and do not actively participate in school sports activities, clubs and societies. Some teachers do not organize field trips and do not make careful use of school facilities at their disposal. This finding agrees with Odunuga and Ajila (2000), Anuna and Onuala (2002) and Junare (2018) who in their various submissions asserted that teacher productivity in Nigeria especially at the primary school level is very low as many teachers are neither effective nor efficient in the discharge of their professional duties. This situation is worrisome and requires drastic measures and policy strategies to stem the tide for the better.

The second finding of this study indicated that the professional status of teaching in primary schools in Zuru Emirate was poor as rated by majority of participants as indicated in table 2. It was found that the slogan of teaching being a noble profession is a mere propaganda as teaching had a poor image in public view. Teaching was not a lucrative profession due to grossly inadequate remuneration, which perpetually keep 
primary school teaches below the poverty line. Teaching was viewed as lacking in monopoly of specialized knowledge, which contributes to employment of untrained personnel to teach in primary schools. Teachers were regarded as dull and unimaginative and are therefore neglected and ignored by the authorities even when their grievances are genuine. Teachers do not feel proud of their profession as they are not respected and honoured in society. Teachers do not pray for their children to become teachers when they grow up. Teachers do not wish to remain on the job for life as they have no strong union to fight for their rights. This finding agrees with Ada (2004), Igwe (2009) and Alfa (2015) who were of the position that the rating of teaching as a profession in Nigeria is very low, especially if compared with other prestigious Professions like Medicine, Law, Engineering, Banking among others.

The third finding of this study was that the condition of service of primary school teachers was fair as teachers' salary in Kebbi state were paid regularly and primary school teachers have the opportunity to combine teaching with farming, petty trading and other menial jobs. It was found that the salaries of primary school teachers were grossly inadequate to cater for the needs of their families. Some teachers do not enjoy regular promotions and neither have offices nor befitting residential accommodation. Some teachers trek for long distances to school due to lack of means of transportation. When primary school teachers fall sick, they can hardly afford quality medical service for themselves and their family members. While they are over loaded with work, the teachers lack special allowances to compensate them for any extra effort. Job insecurity was very high as teachers can be intimated, harassed, threatened and even attacked without serious consequences on the perpetrators. This finding agrees with Balogun (2003); Akpotu and Nwahan (2008); Ekpo, Anuna and Okoli (2012); Abdullahi (2013) and Odor (2014) who contended that the condition of service of teachers in Nigeria is poor as teachers have no job satisfaction and are ever ready to escape the teaching trap on the slightest opportunity of getting another job that offers greener pastures.

The fourth finding of this study indicates that professional status of teaching influences teacher productivity in primary schools in Zuru Emirate of Kebbi State. This implies that when a profession is highly rated, recognized and honoured members of the profession would be proud of it and will be ready to put in their best to excel in that profession. On the other hand, when a profession has little or no recognition, members of that profession are most likely to be discouraged and their low morale might negatively affect their productivity. This finding is in line with Bankole (2001) who conducted a study on job satisfaction among academic staff of Usmanu Danfodiyo University Sokoto, Nigeria and found that when the status of a profession is highly esteemed, members will be motivated to be productive due to feelings of job satisfaction. This finding also confirms the study conducted by Frank (2010) who examined factors affecting job satisfaction among school principals in Zimbabwe Republic. The study found that a good image of a profession encourages workers to strive to be efficient and effective in the discharge of their responsibilities. This implies that the better the condition of service, the higher the productivity of the teachers would most likely become.

\section{Conclusion}

Conclusions of this study are that the level of productivity of primary school teachers in Zuru Emirate of Kebbi State Nigeria was low. This low level of productivity was influenced by the poor status of the teaching profession and unsatisfactory conditions of service under which the teachers are compelled to operate. The focus of policy making therefore, should be on devising strategies that will help to improve the quality of teachers' lesson delivery, record keeping and participation in extra co-curricular activities which are critical indicators of teacher productivity. To achieve this, it is necessary to urgently upgrade the professional status and drastically improve the conditions of service of teachers at the primary school level.

\section{Recommendations for Policy Consideration}

Based on the findings and conclusions of this study, the following recommendations were tendered for policy consideration

1. Efforts should be made by policy makers, school heads and teachers themselves to improve teacher productivity in the following aspects:

a. Regular micro teaching should be emphasized in all Area Offices in all local governments in Zuru Emirate so as to improve teachers lesson delivery and mystery of teaching skills 
b. Head masters of schools should strictly inspect teachers' record keeping on daily basis so as to ensure that they are correctly kept by all teachers.

c. Teachers should make personal efforts to improve on their participation in co-curricular activities so as to improve their overall teaching productivity, enhance their relationship with pupils and colleagues.

2. The Nigerian Union of Teachers (NUT) and Teachers Registration Council (TRC) Ministries of Education, Primary School Education Boards and Local Education Authorities should re-double their efforts at ensuring that only trained teachers are employed to teach. All untrained teachers should be given a definite period to acquire teaching qualifications or be shown the way out. The policy making NCE the minimum teaching qualifications should be revisited and amended so as to make Bachelor of Education (B.Ed) degree the minimum qualification for entry into teaching as is obtainable in other prestigious professions. Grade II Teachers Colleges should be re-established and Grade II Teachers Certificate should be restored to provide a good ordinary level foundation for admission into Colleges of Education and Faculties of Education in Nigeria Universities.

3. The condition of service of teachers should be improved by implementation of the Teacher Salary Scale (TSS) and provision should be made for other attractive allowances and fringe benefits in order to make teaching attractive and to retain existing teachers.

\section{References}

[1] Abdullahi, B. (2013). Influence of administrators' interactive variables and conditions of service on student academic performance in Senior Secondary Schools in Bauchi State. Ph.D Thesis. Usmanu Danfodiyo Universty, Sokoto, Nigeria.

[2] Alfa, L.A. (2015). Educational management and other contemporary problems. Makurdi: Wintoren Books, Nigeria.

[3] Amuna, M.C. \& Onuoha, P (2002). The Nigerian educational system and the effective teacher. In Ekpo, T.M; Amuna M.C. \& Okoli G.L. (eds). Contemporary issues and problems in Nigeria educational system. Enugu. Forth Dimension Publishers.

[4] Balogun, H.A. (2003). Issues in human resource management in educational institutions in Nigeria Journal of Educational Management and Planning I (I), 180-184. Published by National Association of Educational Planners and Managers (NAEPM) Ahmadu Bello University, Zaria.

[5] Bankole, E.E. (2001). Job satisfaction among academic staff of Usmanu Danfodiyo University, Sokoto: Implications for counseling. M.Ed Dissertation. UDUS Sokoto, Nigeria.

[6] Ekpo T.N: Anuna, M.C \& Okoli G.L. (2012). Contemporary issues and problems in the Nigerian education system. Enugu. Forth Dimension Publishers.

[7] Fafunwa, A.B (2004). History of education in Nigeria. London: Oxford University Press.

[8] Fagbamiye, E.O. \& Durosaro, D.O. (eds) (2000). Education and productivity in Nigeria. Published by Nigerian association for educational administrative and planning (NAEAP) Ilorin printed by Haytee Printing and Publishing Company Limited.

[9] Federal Republic of Nigeria (2013). National Policy on Education. Lagos. NERDC Press.

[10] Homby, A.S. (2010). Oxford Advanced Learners Dictionary. Oxford University Press.

[11] Jumare, A.M (2018). Introduction to recurrent issues in educational administration in Nigeria. Zaria. Concept Designs and Prints.

[12] Kpee, M G.G. (2015). Theories and theoretical framework. The researcher's handbook. Owerri; Ezopietro Publishers.

[13] Maduemere, S.C. (2004). Social and philosophical aspects of educational planning. Lagos. Vitanasle Publishing Company.

[14] Manga, S.D. (2015). Introduction to educational management. Sokoto, Usmanu Danfodiyo University Press.

[15] Odor, A.C. (2014). Wage differentials and teacher's productivity in public and private schools in Rivers State. Ph.D. Thesis, University of Port Harcourt, Nigeria. 
[16] Odunuga, \& Ajila, (2000). Measuring teacher productivity and primary school quality: an evaluation of concepts and issues. In Fagbamiye E.O. \& Durosaro, D.O. (ed). Education and productivity in Nigeria. Ilorin: Haytee Press Ltd.

[17] Research Advisor (2006). Table for determining sample size.

[18] Sofoluwe A.O (2000). Issues in measuring teacher productivity. In Fagbamiye, E.O \& Durosaro D.O. (eds). Education and productivity in Nigeria. Ilorin: Haytee Press and publishing company.

[19] Thomas, R.M. (2010). Recruitment, selection and employment: how to hire the right people. Cornell University Press. 